\title{
Åtgärder mot ungdomskriminaliteten sedda mot bakgrunden av kriminalitetens allmänna utveckling i de nordiska länderna under de senaste åren ${ }^{1}$ )
}

Av professor INKERI ANTTILA.

Rubrikens formulering bygger på antagandet, att det föreligger en relation mellan ungdomskriminalitetens utvecklingstendens och påföljdssystemet. Även om det är klart, att det formella påföljdssystemet icke inverkar kausalt, såsom en allena avgörande faktor, är det likväl befogat att söka korrelationer mellan förändringar i påföljdssystemet och kriminalitetens ut-
vecklingstendens.

En empirisk undersökning på samnordisk grund av påföljdssystemets eventuella inverkan förutsätter bl. a. - om klarläggandet av en dylik inverkan överhuvudtaget är möjligt - att de kvantitativa och kvalitativa förändringar, som under senaste år skett i ungdomskriminaliteten i respektive nordiskt land, kan mätas på ett tillförlitligt sätt. En ytterligare förutsättning är att man känner till och kan återgiva påföljdssystemet och dess tillämpning i praktiken samt de förändringar, som eventuellt skett däri, samt att man kan jämföra kriminalitetens utvecklingstendens och påföljdssystemet i de olika nordiska länderna. I fortsättningen undersökes, vilka möjligheter som finns att upp-
fylla dessa förutsättningar.

a) Förändringar inom ungdomskriminaliteten under de senaste åren. Utvecklingstendensen inom ungdomskriminaliteten kan bäst undersökas utgående från den officiella brottsstatistiken, som finns tillgänglig för alla nordiska länder, dels i form av polisstatistik, dels i form av domstolsstatistik. Uppgifter om ungdomskriminalitetens utveckling från och med början av 1950talet har publicerats i olika artiklar i denna tidskrift samt för Danmarks del i ett kommittébetänkande av år $1959^{2}$ ).

Tillgängliga statistiska uppgifter ger vid handen följande: i Danmark minskade ungdomskriminaliteten avsevärt i slutet av 1940-talet och minskningen fortgick ända fram till år 1955 beträffande alla åldersklasser. I Norge minskade ungdomskriminaliteten likaså i slutet av 1940-talet men begynte öka i början av 1950-talet och har, med undantag för åren 1952-53, där-

1) I brist på uppgifter har Island lämnats utanför framställningen.

2) Se redogörelser $\mathrm{i} \mathrm{nr} 4 / 1961$ och i detta nummer samt danska Straffelovskommissionens betænkning $\mathrm{Nr} 232 / 1959$. Se även M M $\phi$ glestue, NKÅ 1958; Verkko, NKÅ 1951-1952, Christiansen, NTfK 1958; Sveri,
NTfK 1956 och samma: Kriminalitet og alder. 
efter ständigt ökat. Kriminaliteten i de yngre åldersklasserna har år 1960 varit nära $2 \frac{1}{2}$ gång så stor som år 1954 ; för $18-20$ åringarnas del är ökningen icke lika märkbar. I Sverige visade ungdomskriminaliteten ett par år efter kriget en nedåtgående tendens men har därefter kontinuerligt ökat i alla åldersklasser och kraftigast bland 15-17 åringar. I Finland skedde efter kriget en avsevärd minskning, som dock på 1950-talet, närmast år 1956, förbyttes till en stigande tendens. Kriminaliteten bland ungdomar under 20 år har under 1950-talet fördubblats. Av ovanstående kan den slutsatsen dragas, att den registrerade ungdomskriminaliteten i alla nordiska länder visat en ökning under efterkrigstiden — något som även har kunnat iakttagas i många andra länder $\left.{ }^{3}\right)$ - men ökningstendensen har likväl varit synnerligen olika till sin styrka och har dessutom infallit under olika år. Det skulle vara lockande att utgående från detta draga slutsatser bl. a. om påföljdssystemets ändamålsenlighet. Härvid bör man likväl fästa uppmärksamhet bl.a. vid följande felkällor :

De statistiska uppgifterna beskriver endast den s. k. registrerade kriminaliteten. Den bild statistiken ger av den totala kriminaliteten är ofullständig och ofta vilseledande. I de för ungdomsbrottsligheten typiska brottsarterna är de dolda fallen $t$. o. m. enligt försiktiga beräkningar många gångar talrikare än de registrerade fallen. Vid en undersökning av ungdomskriminalitetens utveckling $i$ ett land bör man genom specialundersökningar klarlägga, huruvida någon faktor under ifrågakommande tidsperiod har ändrat proportionen mellan den registrerade och den dolda kriminaliteten. Som exempel kan följande omständigheter nämnas:

— förändringar i allmänhetens inställning till ungdomskriminaliteten eller till någon typ därav (Kanske man tidigare genom informella åtgärder redde upp t. ex. sådana fall av skadegörelse och ofog, som numera anmäles till polisen? Fäster man nuförtiden mera eller mindre uppmärksamhet än förr vid lindriga fall av misshandel? Har praxis förändrats beträffande polisanmälan av tillgreppsbrott, som har begåtts i skolor, på arbetsplatser och i varuhus?)

— förändringar beträffande målsägandens möjligheter att erhålla ersättning (Använder man allmännare än förr försäkringsformer, där polisanmälan av brottet utgör villkor för utfående av försäkringsbeloppet?)

förändringar inom polisens verksamhet (Har polisen till sitt förfogande mera eller mindre personal och tekniska hjälpmedel än under tidigare år? Har polisen fått direktiv om att i något

3) Se New Forms of Juvenile Delinquency, United Nations Report 1960 . 
avseende förfara annorlunda än tidigare? Har uppfattningarna om effektiviteten i polisens verksamhet förändrats på något sätt?)

Då man önskar jämföra kriminalitetens utvecklingstendens $i$ olika länder, bör man undersöka, i vilken mån proportionen dold/registrerad kriminalitet vid samma tidpunkt varierar från det ena landet till det andra.

En stor felkälla sammanhängar med olikheterna i sätten att upprätta statistik. Redan lagstiftningsmässiga olikheter leder till att samma rubriker omfattar olika gärningar. Dessutom kan registreringen i olika länder ske på olika stadier av brottsutredningen, vilket bl. a. inverkar på brottsrubriceringen. Då en person inom ett och samma polisdistrikt gör sig skyldig till flera brott genom en gärning eller genom flera gärningar efter varandra, kan det hända att i ett land endast det grövsta brottet införs i statistiken medan i ett annat land samtliga brott tages med. Då en person begår flera brott i olika polisdistrikt eller under olika tidpunkter i samma distrikt, kan man i statistiken använda en eller flera enheter. Dessa och sannolikt många andra olikheter kan avsevärt påverka statistikens totalsummor.

b) Påföljdssystemet och dess tillämpning. I det följande framlägges vissa uppgifter om det påföljdssystem, som tillämpas på unga lagöverträdare i de olika nordiska länderna. Från Norge och Finland kan också uppgifter särskilt för sig erhållas om vissa brottstyper. (Se tabeller sid. 8-14).

Såsom en allmän iakttagelse kan man — trots bristfälligheten i de uppgifter, som skall jämföras med varandra - konstatera, att $\mathrm{i}$ alla andra nordiska länder utom Finland förekommer åtalseftergift mycket allmänt, i synnerhet för personer under 18 år. Synnerligen stora olikheter föreligger beträffande användandet av ovillkorliga frihetsstraff, vilket följande sammanställning utvisar:

$\begin{array}{lcc}\text { Till ovillkorliga frihetsstraff dömda år } & 1958 \\ & 15-17 \text { åringar } & 18-20 \text { åringar } \\ \text { Danmark } & \ldots & 456 \\ \text { Norge } & 10 & 100 \\ \text { Sverige } & 47 & 1024 \\ \text { Finland } & 220 & 524\end{array}$

Om man likväl försöker draga slutsatser om sambandet mellan påföljdssystemet och ungdomskriminalitetens utvecklingstendens, bör man fästa avseende vid bl. a. följande omständigheter: Redan beträffande ett land kan det inom lagstiftningen under exempelvis tio års tid ske förändringar, som inverkar på systemet; likaså har påföljdssystemet de facto kunnat bli annorlunda t. ex. genom förändringar i myndigheternas inre organi- 


\section{DANMARK \\ Åtgärder mot unga lagöverträdare \\ 15-17 årige $\left.{ }^{1}\right)$}

\begin{tabular}{|c|c|c|c|c|}
\hline \multirow{2}{*}{$\AA ̊ \AA r$} & \multirow[b]{2}{*}{$\begin{array}{l}\text { Strafferegister- } \\
\text { tiltalefrafald }{ }^{2} \text { ) }\end{array}$} & \multirow[b]{2}{*}{$\begin{array}{l}\text { Andre tiltale- } \\
\text { frafald }^{3} \text { ) }\end{array}$} & \multicolumn{2}{|c|}{ Domfældelser } \\
\hline & & & boder & $\begin{array}{c}\text { andre } \\
\text { reaktioner }\end{array}$ \\
\hline 1951 & $\ldots$ & 309 & \multicolumn{2}{|c|}{$\left.43^{4}\right)$} \\
\hline 1952 & 735 & 343 & \multicolumn{2}{|c|}{$\left.54^{4}\right)$} \\
\hline 1953 & 673 & 360 & \multicolumn{2}{|c|}{$\left.62^{4}\right)$} \\
\hline 1954 & 758 & 479 & \multicolumn{2}{|c|}{$\left.81^{4}\right)$} \\
\hline 1955 & 774 & 533 & 36 & 38 \\
\hline 1956 & 845 & 581 &.$\left.^{5}\right)$ & 43 \\
\hline 1957 & 1074 & 601 &.$\left.^{5}\right)$ & 37 \\
\hline 1958 & 1082 & 715 &.$\left.^{5}\right)$ & 48 \\
\hline 1959 & 1311 & & & \\
\hline
\end{tabular}

1) Talen gäller endast strafflagsöverträdelser.

Talen är absoluta tal.

Talen omfattar både män och kvinnor.

$\left.{ }^{2}\right)$ Dessa åtalseftergifter omfattar åtalseftergifter med andra villkor än betalning av böter och/eller ersättning. Nästan alla „Strafferegister-tiltalefrafald " i här berörda åldersgrupper kommer att vara åtalseftergifter med villkor om barn- och ungdomsvård.

Talen för år 1951 kan inte erhållas.

3) Medan övriga tal härstammar från Statistisk Departements kriminalstatistik, är talen för här omtalade fall av åtalseftergift (utan villkor — eller med villkor om betalning av böter) tagna ur årsberättelserna avgivna av landsnævnet for børneforsorg (före 1958 - direktoratet for børne- og ungdomsforsorgen); bland dem ingår ej „politisager" (däribland „brugstyverier").

Här kan icke ges upplysning om talen för här omtalade fall av åtalseftergift inom åldersgruppen $18-20$ år.

4) För åren 1951-54 är en uppdelning enligt sanktion inom åldersgrupperna inte möjlig.

5) Statistiken över dömda för åren 1956—58 omfattar icke bötesdomar.

sation, genom inrättande av nya anstalter eller till följd av personalbyte. Vid en jämförelse mellan olika länder kan det åter vara svårt att upptäcka dolda olikheter, t. ex. då påföljder, som har samma benämning och som i lagstiftningen kanske avsetts att tillämpas på samma sätt, i realiteten, till följd av t. ex. olikheter i resurser eller i personalens nivå, har verkat på olika sätt. Kriminalvård $\mathrm{i}$ frihet kan sålunda $\mathrm{i}$ verkligheten innebära synnerligen olika åtgärder; ungdomsanstalterna kan, trots sina likartade namn, i praktiken bygga på mycket olika behandlingsformer. Detta beror delvis på att också det klientel, som blir föremål för påföljderna, är olika i olika länder. Olikheter föreligger t. ex. beträffande åldersfördelningen och beträffande kriminalitetens art men föranleds också ofta av att en påföljd, som i ett land kan förekomma allmänt eller t. o. m. utgöra regel, i ett annat land kanske tillämpas mycket sällan. 
(Danmark)

18-20 årige $\left.{ }^{1}\right)$

\begin{tabular}{|c|c|c|c|c|c|c|c|c|c|c|}
\hline \multirow[b]{2}{*}{$\AA ̊ \AA r$} & \multirow[b]{2}{*}{$\begin{array}{l}\text { Strafreregi- } \\
\text { stertilitale- } \\
\text { frafald }^{2} \text { ) }\end{array}$} & \multirow[b]{2}{*}{$\begin{array}{c}\text { be- } \\
\text { tinget } \\
\text { dom }\end{array}$} & \multicolumn{4}{|c|}{ Domfældelser } & \multirow[b]{2}{*}{$\begin{array}{l}\text { straf udstsaet } \\
\text { m. vareteggts. } \\
\text { fngsl. }\end{array}$} & \multirow[b]{2}{*}{$\begin{array}{l}\text { bø- } \\
\text { der }\end{array}$} & \multirow[b]{2}{*}{$\begin{array}{l}\text { andre } \\
\text { reak. } \\
\text { tioner }\end{array}$} & \multirow[b]{2}{*}{ Ialt } \\
\hline & & & $\begin{array}{c}\text { ungdoms- } \\
\text { feng- } \\
\text { sel }\end{array}$ & $\begin{array}{c}\text { ube- } \\
\text { tinget } \\
\text { fngsil.straf }\end{array}$ & $\begin{array}{l}\text { ube- } \\
\text { tinget } \\
\text { haffe- } \\
\text { straf }\end{array}$ & $\begin{array}{c}\text { mili- } \\
\text { tere } \\
\text { arrest }\end{array}$ & & & & \\
\hline 1951 & & 816 & & & & & $\left.57^{3}\right)$ & & & 1373 \\
\hline 1952 & 226 & 770 & & & & & $\left.91^{3}\right)$ & & & 1361 \\
\hline 1953 & 205 & 715 & & & & & $\left.647^{3}\right)$ & & & 1262 \\
\hline 1954 & 195 & 706 & & & & & $\left.28^{3}\right)$ & & & 1334 \\
\hline 1955 & 212 & 695 & 84 & 276 & 67 & 27 & 5 & 114 & 17 & 1285 \\
\hline 1956 & 200 & 725 & 126 & 208 & 69 & 46 & 4 &.$\left.^{5}\right)$ & 19 & $\left.1197^{5}\right)$ \\
\hline 1957 & 205 & 759 & 113 & 230 & 88 & 35 & 1 & ..5) & 27 & $\left.1253^{5}\right)$ \\
\hline 1958 & 183 & 746 & 113 & 188 & 108 & 45 & 2 &..$\left.^{5}\right)$ & 17 & $\left.1219^{5}\right)$ \\
\hline
\end{tabular}

1) Talen gäller endast strafflagsöverträdelser.

Talen är absoluta tal.

Talen omfattar både män och kvinnor.

2) Dessa åtalseftergifter omfattar åtalseftergifter med andra villkor än betalning av böter och/eller ersättning. Nästan alla „Straffefegister-tiltalefrafald " i här berörda åldersgrupper kommer att vara åtalseftergifter med villkor om barn- och ungdomsvård.

Talen för år 1951 kan inte erhållas.

3) För åren 1951-54 är en uppdelning enligt sanktion inom ålders-

grupperna inte möjlig.

4) Omfattar särskilda ătgärder — t. ex. „åndssvageforsorg“ — för psykiskt efterblivna.

5) Statistiken över dömda för åren 1956—58 omfattar icke bötesdomar.

c) Påföljdssystemets inverkan på ungdomskriminalitetens utvecklingstendens. Också om det är möjligt att med hjälp av specialundersökningar klarlägga kriminalitetens ,verkliga“ innebörd i de olika nordiska länderna, återstår ännu frågan, om det är möjligt att undersöka påföljdssystemets inverkan på ungdomskriminaliteten. Med begagnande av juridisk terminologi lyder frågan: Kan man mäta påföljdssystemets individual- och generalpreventiva verkan?

Vid en undersökning av individualpreventionen förfar man traditionsenligt så, att man som undersökningsgrupp utväljer personer som blivit föremål för en viss påföljd; deras recidivism under en viss observationstid jämföres sedan antingen med ,den allmänna kriminalitetsrisken" eller med återfallsfrekvensen bland personer som blivit föremål för någon annan påföljd. Jämförelsen bygger på antagandet, att förekomsten av dolda fall är lika stor i vardera gruppen. Undersökningsmaterial och kontrollmaterial måste delas upp i flera undergrupper bl. a. därför, att risken för återfall är erkänt olika stor bland personer dömda för olika typer av brott. Den största svårigheten torde ligga i 


\section{NORGE}

I. Atgärder mot unga lagöverträdare

\begin{tabular}{|c|c|c|c|c|c|c|c|}
\hline År & $\begin{array}{l}\text { Påtaleunn- } \\
\text { latelse }\end{array}$ & Böt & $\begin{array}{c}\text { Sikring } \\
\text { uten straff }\end{array}$ & $\begin{array}{c}\Delta \text { rbeids- } \\
\text { skole }\end{array}$ & $\underset{\text { betinge }}{\mathrm{Fe}}$ & $\begin{array}{l}\text { ssel } \\
\text { ubetinget }\end{array}$ & $\begin{array}{c}\text { Total- } \\
\text { tall }\end{array}$ \\
\hline \multicolumn{8}{|c|}{ 14-17 åriga } \\
\hline 1951 & 568 & 6 & 1 & . & 27 & 4 & 606 \\
\hline 1952 & 588 & 9 & 2 & 2 & 25 & 5 & 631 \\
\hline 1953 & 556 & 6 & - & 7 & 25 & 5 & 599 \\
\hline 1954 & 581 & 11 & 1 & 6 & 20 & 3 & 622 \\
\hline 1955 & 744 & 14 & 3 & 3 & 25 & 5 & 794 \\
\hline 1956 & 958 & 13 & - & 11 & 37 & 6 & 1025 \\
\hline 1957 & 1258 & 24 & - & 10 & 46 & 3 & 1341 \\
\hline 1958 & 1519 & 30 & - & 6 & 43 & 4 & 1602 \\
\hline 1959 & 1731 & 31 & - & 8 & 51 & 5 & 1826 \\
\hline \multicolumn{8}{|c|}{$18-20$ åriga } \\
\hline 1951 & 250 & 33 & 6 & - & 153 & 71 & 513 \\
\hline 1952 & 270 & 43 & 5 & 4 & 133 & 62 & 517 \\
\hline 1953 & 267 & 27 & 3 & 10 & 141 & 66 & 514 \\
\hline 1954 & 254 & 43 & 2 & 12 & 123 & 77 & 511 \\
\hline 1955 & 237 & 56 & 1 & 12 & 138 & 71 & 515 \\
\hline 1956 & 290 & 55 & 3 & 13 & 170 & 46 & 577 \\
\hline 1957 & 331 & 44 & 1 & 16 & 178 & 60 & 630 \\
\hline 1958 & 336 & 51 & 3 & 33 & 222 & 67 & 712 \\
\hline 1959 & 299 & 48 & 1 & 23 & 243 & 85 & 699 \\
\hline
\end{tabular}

att de grupper som blir föremål för olika slags påföljder som regel också i övrigt är olika; det kan t. ex. antagas, att villkorligt och ovillkorligt dömda skiljer sig från varandra därigenom, att den förra kategorin i allmänhet anpassar sig bättre till samhället $^{4}$ ). Egentliga experiment, där domstolarna i undersökningssyfte skulle tillämpa olikartade påföljder i fullständigt likartade fall eller där påföljden skulle bestämmas genom lottdragning är i allmänhet icke möjliga utan att rättviseprincipen kränkes ${ }^{5}$ ). Man har därför vid kriminologiska undersökningar varit tvungen att nöja sig antingen med att använda material, som från början varit olika, eller med att enbart jämföra personer, som vid verkställighet av frihetsstraff har placerats $i$ anstalter av

4) Detta har i allmänhet även påpekats i undersökningarna, se t. ex. Eriksson-Jansson-Larsson, SOU 1956:55, s. 53.

5) I en ny amerikansk undersökning har följande förfarande tillämpats: Ungdomsdomaren beslöt först, om den unga lagöverträdaren skulle dömas till ovillkorligt eller villkorligt frihetsstraff, men därefter bestämde han $\mathrm{i}$ alla fall genom lottdragning, vilka som skulle erhålla särskild vård i frihet och vilka som skulle placeras i ungdomsfängelse. Den förra gruppen var experimentgrupp, den senare kontrollgrupp. Se Empey-Rabow, American Sociological Review, Oct. 1961, s. 694. 
II. Åtgärder mot unga lagöverträdare

(Norge) Vinningsförbrytelser

\begin{tabular}{|c|c|c|c|c|c|}
\hline$\AA \mathbf{r}$ & $\begin{array}{l}\text { Åtalseftergift eller } \\
\text { påföljdseftergift }\end{array}$ & $\begin{array}{l}\text { Endast } \\
\text { böter }\end{array}$ & $\begin{array}{l}\text { Villkorligt } \\
\text { frihetsstraff }\end{array}$ & $\begin{array}{l}\text { Ovillkorligt } \\
\text { frihetsslratf }\end{array}$ & $\begin{array}{c}\text { Till- } \\
\text { samman }\end{array}$ \\
\hline \multicolumn{6}{|c|}{ 14-17 åriga } \\
\hline 1951 & 474 & - & 20 & 3 & 497 \\
\hline 1952 & 505 & 2 & 17 & 3 & 527 \\
\hline 1953 & 476 & 5 & 15 & 11 & 517 \\
\hline 1954 & 489 & 2 & 15 & 8 & 514 \\
\hline 1955 & 633 & 6 & 20 & 6 & 665 \\
\hline 1956 & 881 & 5 & 31 & 12 & 929 \\
\hline 1957 & 1135 & 15 & 38 & 9 & 1197 \\
\hline 1958 & 1357 & 22 & 33 & 7 & 1419 \\
\hline 1959 & 1516 & 21 & 42 & 10 & 1589 \\
\hline 1960 & 1629 & 24 & 93 & 16 & 1762 \\
\hline \multicolumn{6}{|c|}{$18-20$ åriga } \\
\hline 1951 & 164 & 3 & 112 & 52 & 331 \\
\hline 1952 & 213 & 12 & 92 & 53 & 370 \\
\hline 1953 & 202 & 8 & 105 & 57 & 372 \\
\hline 1954 & 183 & 12 & 90 & 75 & 360 \\
\hline 1955 & 183 & 22 & 88 & 59 & 352 \\
\hline 1956 & 244 & 21 & 124 & 35 & 424 \\
\hline 1957 & 263 & 18 & 137 & 62 & 450 \\
\hline 1958 & 260 & 19 & 170 & 82 & 531 \\
\hline 1959 & 237 & 32 & 175 & 81 & 525 \\
\hline 1960 & 204 & 33 & 259 & 102 & 598 \\
\hline
\end{tabular}

olika typer eller annars blivit föremål för olika slags behandling. Man har stundom försökt övervinna svårigheterna genom att på förhand bedöma den sannolika anpassningsförmågan hos personer inom undersöknings- respektiva kontrollgruppen. I sådana undersökningar har svårigheter kumnat yppa sig bl. a. däri, att intagning i anstalt, vilken skett båda i undersöknings- och kontrollgruppen, har varit en sådan avgörande grundfaktor, vid sidan av vilken olikheter, kanske föranledda av behandlingen, icke kommit till synes ${ }^{6}$ ). Jämförande undersökningar beträffande de nordiska länderna vore synnerligen värdefulla, eftersom man kunde draga nytta av „färdiga“ olikheter i påföljdssystemen. Bland de svårigheter, som uppstår vid en jämförelse kan nämnas, att återfallsfrekvensen efter frigivning från anstalt väsentligen påverkas av de förhållanden, till vilka den frigivne kommer och dessa kan naturligtvis icke vara fullständigt lika i olika länder. 


\section{SVERIGE}

Ålgärder mot unge lagöverträdare

\begin{tabular}{|c|c|c|c|c|c|c|c|c|}
\hline \multirow[t]{2}{*}{ 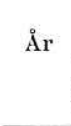 } & \multicolumn{2}{|c|}{$\begin{array}{c}\text { Åtalseftergift(1) } \\
\text { eller } \\
\text { påföljdseftergift }\end{array}$} & \multicolumn{2}{|c|}{$\begin{array}{l}\text { Överlämnande } \\
\text { till skydds- } \\
\text { uppostran }\end{array}$} & \multicolumn{2}{|c|}{$\begin{array}{l}\text { Villkorligt }{ }^{2} \text { ) } \\
\text { frihetsstraff }\end{array}$} & \multicolumn{2}{|c|}{$\begin{array}{l}\left.\text { ()villkorligt } t^{3}\right) \\
\text { frihetsstraff }\end{array}$} \\
\hline & $\underbrace{15-17}$ & $18-20$ & $15-17$ & $18-20$ & $15-17$ & $18-20$ & $15-17$ & $18-20$ \\
\hline 1951 & & 2984 & $\cdots$ & . & 208 & 1036 & 28 & 517 \\
\hline 1952 & & 3413 & . & $\ldots$ & 202 & 1053 & 30 & 487 \\
\hline 1953 & & 3471 & $\ldots$ & . & 234 & 1048 & 24 & 471 \\
\hline 1954 & & 4126 & 23 & 37 & 157 & 1013 & 11 & 530 \\
\hline 1955 & & 4503 & 58 & 45 & 98 & 1074 & 22 & 596 \\
\hline 1956 & & 5096 & 69 & 56 & 116 & 1223 & 19 & 747 \\
\hline 1957 & & 6371 & \multicolumn{2}{|c|}{176} & 139 & 1360 & 24 & 792 \\
\hline 1958 & & 7468 & 304 & 22 & 164 & 1668 & 47 & 1014 \\
\hline 1959 & & 8325 & 355 & 28 & 407 & 2032 & 108 & 1171 \\
\hline
\end{tabular}

1) Omfattar eftergift enligt 1944 års lag för strafflagsbrott (utom SL 11:10-11) samt eftergift enligt barnavårdslagen och ungdomsfängelselagen men ej eftergift enligt nykterhetsvårdslagen eller $\mathrm{RB} 20: 7$.

2) Omfattar även villkorligt anstånd med straffsådömande.

3) Omfattar även ungdomsfängelse och förvaring.

Åldersuppgifterna avse åldern vid domen.

Det är givet, att det skulle ställa sig ännu svårare att undersöka någon viss påföljds allmänpreventiva verkan ${ }^{7}$ ). I äldre kriminologiska undersölnningar granskades ibland påföljdssystemet eller någon enskild del därav såsom en seperat enhet, lösryckt både från andra former av social kontroll och från den utveckling, som samtidigt skedde i samhället, och man kunde då göra gällande, att t. ex. en ökad användning av en viss påföljd var „orsak“ till vissa förändringar i kriminalitetssituationen. Då det är svårt att ordna sådana experimentssituationer, där man för skilda delar av en stat skulle genomföra olika slags lagstiftning och där man sedan skulle granska resultaten, är det förståeligt, att de olika uppfattningar, som framförts om allmänpreventionen, har förblivit empiriskt overifierade påståenden. En svårighet bland många andra är, att man icke vet, när en ökad användning av en viss påföljd är tecken på ändrad praxis och när den åter tyder på förändringar i själva kriminaliteten. Brottstypernas rubriker $\mathrm{i}$ den officiella statistiken ger nämligen ingalunda alltid tillräcklig kunskap om fallens karaktär, eftersom samma rubrik, t. ex. stöld eller rån, täcker en vid skala variationsmöjligheter från lindriga till grova brott.

Om man med samnordiska undersökningar vill klarlägga

${ }^{7}$ ) Se Andenæs, Det tredje nordiske kriminologiseminar 1960, s. $38-45$. 
FINLAND

I. Åtgärder mot unga lagöverträdare

\begin{tabular}{|c|c|c|c|c|c|c|}
\hline 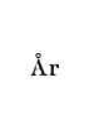 & $\begin{array}{l}\text { Åtals- } \\
\text { efter- } \\
\text { gift }\end{array}$ & $\begin{array}{l}\text { Påföljds- } \\
\text { efter* } \\
\text { gift }\end{array}$ & Böter & $\begin{array}{l}\text { Villkorligt } \\
\text { frihets- } \\
\text { straff }\end{array}$ & $\begin{array}{c}\text { Ovillkorligt } \\
\text { frihetsstraff } \\
\text { (ungdomsfängelse, } \\
\text { allmänt fängelse, } \\
\text { arbetskoloni) }\end{array}$ & $\begin{array}{c}\text { Ställts under } \\
\text { åtal } \\
\text { (enligt } \\
\text { polisstati- } \\
\text { stiken) }\end{array}$ \\
\hline \multicolumn{7}{|c|}{$15-17$ åriga } \\
\hline 1951 & 377 & 167 & $\ldots$ & 391 & 87 & 2448 \\
\hline 1952 & 411 & 171 & . & 356 & 114 & 2459 \\
\hline 1953 & 467 & 139 & . & 396 & 126 & 3585 \\
\hline 1954 & 542 & 234 & . & 400 & 99 & 4016 \\
\hline 1955 & 480 & 252 & 4012 & 409 & 84 & 4296 \\
\hline 1956 & 347 & 334 & 4530 & 456 & 92 & 5748 \\
\hline 1957 & 520 & 472 & 7233 & 665 & 171 & 8295 \\
\hline 1958 & 573 & 485 & 7424 & 758 & 220 & 9850 \\
\hline 1959 & 566 & & & & & 10741 \\
\hline 1960 & 689 & & & & & 13354 \\
\hline \multicolumn{7}{|c|}{$18-20$ airiga } \\
\hline 1951 & . & . & . & 457 & 502 & 9548 \\
\hline 1952 & . & . & $\ldots$ & 438 & 433 & 10160 \\
\hline 1953 & . & . & . & 426 & 481 & 11455 \\
\hline 1954 & . & . & . & 425 & 407 & 12017 \\
\hline 1955 & . & . & 8863 & 431 & 401 & 12149 \\
\hline 1956 & . & . & 9137 & 466 & 414 & 13178 \\
\hline 1957 & . & . & 12299 & 490 & 457 & 16114 \\
\hline 1958 & . & . & 12334 & 545 & 524 & 17285 \\
\hline 1959 & . & . & & & & 18486 \\
\hline 1960 & . & . & & & & 20859 \\
\hline
\end{tabular}

frågan om påföljdernas allmänpreventiva verkan, borde man på kriminalpolitikens område fästa uppmärksamheten inte blott vid lagstiftningen utan också vid systemets funktion i praktiken. Det gäller då att studera allmänhetens kännedom om lagreglerna, uppfattningarna om den polisiära verksamhetens effektivitet och åsikterna om vissa påföljders stränghet respektive mildhet. Därtill är det nödvändigt att undersöka andra former av social kontroll samt att försöka bedöma huru ekonomiska och andra samhälleliga faktorer har påverkat kriminaliteten under samma tid.

Ovan har nödvändigheten av samnordiska undersökningar flera gånger poängterats. Av framställningen torde ha framgått, att en av de första uppgifterna måste vara att utreda jämförbarheten av de olika ländernas brottsstatistik; en sådan undersökning är också redan på planeringsstadiet. Planerna, som först tog form i Danmark, har utvecklats vidare bl. a. på det Nordiska kriminologiseminariet år 1960. Ett nytt skede inträdde i och med 
(Finland)

II. Åtgärder mot unga lagöverträdare SL 28 (stöld, snatteri, inbrott)

\begin{tabular}{|c|c|c|c|c|c|c|}
\hline$\AA \mathbf{r}$ & $\begin{array}{l}\text { Atals- } \\
\text { efter- } \\
\text { gift }\end{array}$ & $\begin{array}{l}\text { Påföljds- } \\
\text { efter- } \\
\text { gift }\end{array}$ & $\begin{array}{l}\text { Endast } \\
\text { böter }\end{array}$ & $\begin{array}{l}\text { Villkorligt } \\
\text { frihets- } \\
\text { straff }\end{array}$ & $\begin{array}{l}\text { Ovillkorligt } \\
\text { frihets- } \\
\text { straff }\end{array}$ & $\begin{array}{c}\text { Ställts } \\
\text { under åtal } \\
\text { (enligt polis- } \\
\text { statistiken) }\end{array}$ \\
\hline
\end{tabular}

\begin{tabular}{rrrrrrr}
\hline \multicolumn{7}{c}{ 15-17 åriga } \\
1951 & 36 & 93 & $\ldots$ & 273 & 55 & 875 \\
1952 & 60 & 96 & $\ldots$ & 226 & 77 & 768 \\
1953 & 55 & 75 & $\ldots$ & 272 & 83 & 1080 \\
1954 & 81 & 151 & $\ldots$ & 254 & 66 & 1052 \\
1955 & 63 & 160 & 123 & 255 & 57 & 1098 \\
1956 & 23 & 189 & 111 & 283 & 66 & 1408 \\
1957 & 45 & 234 & 151 & 453 & 105 & 1846 \\
1958 & 46 & 255 & 132 & 503 & 144 & 2176 \\
1959 & 99 & & & & & 2397 \\
1960 & 82 & & & & & 2913 \\
\hline & & & $18-20$ & åriga & & \\
1951 &. &. &. & 217 & 178 & 1010 \\
1952 &. &. &. & 185 & 152 & 855 \\
1953 &. &. &. & 188 & 155 & 956 \\
1954 &. &. & $\ldots$ & 155 & 131 & 845 \\
1955 &. &. & 106 & 183 & 110 & 865 \\
1956 &. &. & 115 & 197 & 118 & 986 \\
1957 &. &. & 139 & 204 & 174 & 1421 \\
1958 &. &. & 149 & 262 & 210 & 1555 \\
1959 &. &. & & & & 1684 \\
1960 &. &. & & & & 1762 \\
\hline
\end{tabular}

att det Nordiska samarbetsrådet för kriminologi, som grundades år 1961 och som från och med början av innevarande år påbörjat sin egentliga verksamhet, upptog undersökningen på sitt program. Planen upptar fyra delprojekt:

1) Undersökning av den faktiska ungdomskriminaliteten.

2) Utredning av olikheter beroende på lagstiftning och sättet att upprätta statistik.

3) Utredning av polisens registreringspraxis.

4) Utredning av olikheter i påföljdssystemet. ${ }^{8}$ )

Den samnordiska undersökningen kommer att kräva flera års arbete. Den är till sin natur grundforskning, och först sedan den blivit färdig, finns det tillräckliga förutsättningar för att studera ungdomskriminalitetens utvecklingstendens och påföljdssyste-

8) Mera detaljerade planer presenteras vid kriminalistmötet sommaren 1962. 
mets andel däri. Dessa målsättningar förefaller otvivelaktigt fjärran för dem, som dagligen har att fatta kriminalpolitiska avgöranden och som kommer att tillämpa påföljdssystemet $i$ praktiken, och det är förståeligt att de snabbt hoppas få enkla och entydigt tillämpliga forskningsresultat. Men även om resultat, som gåve anvisningar för praktiken, ännu ej står till buds, är det uppenbart, att man kan diskutera det nuvarande påföljdssystemet utgående från de erfarenheter, som finns beträffande ändamålsenligheten i vissa förfaringssätt. Systemet kan granskas t. ex. i rationaliseringssyfte samt från rättviseprincipens synpunkt. Som en slags förberedande diskussion med tanke på de kommande undersökningarna kan man likaså försöka utreda i vilken mån de syften, som lagstiftaren uppställt för en viss påföljdsform och dess tillämpning i praktiken överensstämmer med varandra. ${ }^{9}$ ) Framför allt kan en sådan diskussion ge anvisning om var de mest fruktbringande forskningsobjekten och -hypoteserna står att finna. I fortsättningen av denna framställning strävar jag till att taga upp vissa sådana problem till diskussion.

På grund av ämnets omfattning begränsar jag framställningen till straffmyndiga eller således för Norges del till dem, som fyllt 14 år, och för de andra nordiska ländernas del till dem, som fyllt 15 år. Som övre gräns ställes 21 år, eftersom denna ålder åtminstone tillsvidare $\mathrm{i}$ allmänhet är övre gräns i specialbestämmelserna rörande unga lagöverträdare.

\section{Några synpunkter på påföljdssystemet.}

I det nordiska systemet för behandling av unga lagöverträdare har beslut om påföljder och påföljdernas genomförande i praktiken anförtrotts dels åt myndigheter inom socialförvaltningen och dels åt myndigheter inom justitieförvaltningen. Dessa myndigheters åtgärder har ofta ansetts vara olika till sin natur, en del av dem anses innebära „vård“ andra ,straff“. Att behandla de två myndigheternas åtgärder separat försvårar emellertid skapandet av en helhetsuppfattning av systemet. Då dessutom samverkan mellan myndigheterna framträder i flera olika kombinationer i de nordiska länderna, har jag avstått från en dylik tudelning enligt förvaltningsgren.

Jag har helt förbigått de frågor, som rör det nordiska systemets ändamålsenlighet och de tänkbara alternativen, barn-, ungdomsoch familjedomstolar. Ett övervägande flertal i alla nordiska länder synes i varje fall hålla fast vid det nuvarande systemet.10)

$\left.{ }^{9}\right)$ Se Sveri-Nyquist, Eksempler på analyser av kriminalpolitiske tiltak, Nordisk forskningsseminar i kriminologi 1958, s. $80-82$.

10) Se t. ex. svenska förslaget till Skyddslag av år 1956 och Brottsbalk av år 1962, norska kommittébetänkandet St.meld. nr 51, 1960-61, danska Straffelovskommissionens Betænkning år 1959 samt diskussioner i de nordiska kriminalistföreningarna, NKÅ 1958 och 1959. 
Åldersgränsen för straffmyndighet begränsar i det nordiska systemet på samma gång även domstolarnas behörighet. Nämnda begränsning har man velat eliminera genom att möjliggöra att skuldfrågan vid behov kunde avgöras av domstol också beträffande dem, som är under 15 (14) år (,,bevistalan“ i svenska förslaget år 1956 ; ,retslig skyldafg $\phi$ relse uden sanktionsfastsæettelse" i danska förslaget av år 1959). Frågan om höjning av straffmyndighetsåldern har dels framkommit såsom konformitetssträvanden vid förslag om att åldern i Norge skulle höjas från 14 till 15 år, dels såsom en strävan att få barnavårdslagens och strafflagens åldersgränser att överensstämma, vilket i Finland kunde ske så att åldersgränsen i strafflagen höjdes från 15 till 16 år. Men det har också framkommit förslag om att straffmyndighetsåldern borde höjas till 18 år; åsiktsmajoriteten i de nordiska länderna har likväl ej ställt sig på denna ståndpunkt, vilken skulle innebära att icke ens bötesstraff kunde ådömas personer under 18 år.

Tillämpningen av ovillkorliga frihetsstraff på unga lagöverträdare utgör ett specialproblem, som i synnerhet i samband med de svenska lagstiftningsreformerna har blivit föremål för mycken diskussion. En del har krävt att anstaltsvård inom barnavården skulle göras till det enda alternativet beträffande ungdomar under 18 år, andra åter har ansett att en störra valfrihet vore fördelaktigare och att det $i$ vissa fall vore nödvändigt att kunna tillgripa ovillkorliga frihetsstraff. Då man söker nå fram till en lösning, behövs kunskaper om systemets faktiska funktion och överväganden om vad ett fastare infogande av barn- och ungdomsvården $\mathrm{i}$ systemet för social kontroll $\mathrm{i}$ praktiken skulle komma att innebära. ${ }^{11}$ )

I följande uppdelning sar jag avstått från att klassificera åtgärderna enligt de myndigheter, som bestämmer dem, eller enligt den omständigheten, huruvida de benämnes straff- eller vårdåtgärder. ${ }^{12}$ ) Jag har däremot såsom en väsentlig indelningsgrund ansett frågan, huruvida faktisk förlust av friheten hör till på-

11) I den internationella kriminalpolitiska diskussionen har man lancerat en ny grupp benämnd ,unga vuxna“. Här må nämnas att det genom en ändring av $\$ 41$ i danska strafflagen har stadgats, att $21-23$ ăringar i särskilda fall kan förordnas till ungdomsfängelse; i Finland är enligt 1940 års lag åldersgränsen för placering i ungdomsfängelse likaså 21 år. (I Finland avgör fängelsedomstolen frågan om placering i ungdomsfängelse först sedan straffverkställigheten begynt.)

12) Se den nya definitionen på begreppet straff, som finns i United Nations Report 1960 s. $60-61$, enligt vilken ,the term 'punishment' means those measures which in different ways involve restriction of certain rights ... among other things, fines, restitution, compulsory attendance at particular centres or institutions, detention and deprivation of freedom". Se också Sveri, St.meld. 51, s. 9. 
följden eller ej. Enligt detta har uppdelningen format sig på följande sätt:

A. Åtgärder i frihet

1. åtalseftergift

2. påföljdseftergift

3. villkorlig dom i dess olika former

4. bötesstraff

B. Åtgärder i anstalter

1. frihetsstraff $i$ allmänt fängelse

2. specialpåföljder i ungdomsanstalter (t. ex. skolhem, oppdragelsehjem, verneskole, ungdomsfängelse samt veckoslutsarrest och andra kortvariga påföljder)..13)

A. Åtgärder i frihet.

1. Ätalseftergift.

Åtalseftergift tillämpas på unga lagöverträdare dels som ett uttryck för opportunitetsprincipen, dels i avsikt att ersätta straff med vårdåtgärder, som är bättre lämpade för det enskilda fallet; sistnämnda tillämpningsform bör anses vara en typ av specialbehandling för unga lagöverträdare. I Sverige, Norge och Danmark har åtalseftergiften fått en så vidsträckt användning, att av lagöverträdare under 18 år knappa 10 \% ställes inför domstol; det huvudsakliga ansvaret har således klart övergått till andra myndigheter. I Finland har åtalseftergift - som enligt lag endast kan tillämpas vid lindriga brott begångna av personer under 18 år — icke på långt när fått lika stor tillämpning.

Till åtalseftergiften hör två skeden: åklagarmyndighetens avgörande och barnavårdsmyndighetens beslut. Åklagaren har att avgöra både skuldfrågan och frågan om avstående från åtal; i det nuvarande systemet har således vissa uppgifter, som av gammalt hört till domstolarna, överförts till andra organ. Rättssäkerheten ökas därav att beslut om åtalseftergift i Sverige, Norge och Danmark ankommer på högre åklagarmyndigheter; i ett reformförslag av år 1950 har det föreslagits, att man också i Finland skulle övergå till detta system; i Danmark äger dessutom en „,retslig forunders $\varnothing$ gelse“ rum vid domstol. Det har ofta i offentligheten betonats, att åtalseftergift ej får bli en kompromisslösning i de fall, då skuldfrågan ej är fullständigt utredd; åtalseftergift innebär ej att saken nedlägges eller att ett friande utslag

13) Indelningen blir ologisk därför att till vissa påföljder undantagsvis kan höra också en annan påföljd. Till åtalseftergift kan sålunda fogas anstaltsvistelse, till villkorlig dom förordnande till anstalt, och bötesstraff kan i vissa länder ådömas jämte andra påföljder. 
gives, eftersom det hör till åklagarens skyldigheter att anmäla saken till barnavårdsmyndigheterna. Dessa kan i sin tur skrida till långt gående vårdåtgärder med den inträffade lagstridiga handlingen som indikation på missanpassning.

Åklagarens beslut om åtalseftergift överflyttar ansvaret för behandlingen på barnavården. Ålklagarens avgörande underlättas av upplysningar om den unga lagöverträdarens personlighet samt av möjligheten att på förhand kontrollera barnavårdens åtgärder; i Norge och Danmark — och i praktiken också i Sverige - bör åklagaren erhålla utlåtande från barnavårdsmyndigheterna, förrän han fattar sitt beslut. Utlåtandet kan vara till nytta också därigenom att det befrämjar beaktandet av behandlingssynpunkter. Att saken härigenom fördröjes är likväl en nackdel.

Ett beslut om åtalseftergift grundar sig på antagandet, att barnavårdsmyndigheterna övertager saken. Konflikter kan uppstå mellan myndigheterna, ifall barnavårdsmyndigheterna icke vidtager några åtgärder eller ifall de förfar på annat sätt än vad åklagaren önskat. I princip är vardera myndighetens behörighet självständig, men det är uppenbart, att det är barnavårdsmyndigheternas skyldighet att $i$ varje enskilt fall undersöka saken och fatta beslut därom; ett avvikande från det utlåtande, som på förhand har givits åklagaren, förutsätter synbarligen särskilda skäl eller en ändring i förhållandena.

Barnavårdsmyndigheternas ställning är såtillvida förmånlig, att de officiellt icke behöver fästa avseende vid mera än en synpunkt, behandlingsbehovet, och de kan därvid bedöma vederbörande persons vårdsituation som helhet med beaktande även av hela familjens vårdbehov. I realiteten ställes likväl på barnavårdsmyndigheterna samma förväntningar som på de myndigheter, som i allmänhet omhänderhar den sociala kontrollen, och man anser det klart, att eventuella åtgärder bör innefatta drag karakteristiska för negativa sanktioner. Såsom Christie och Persson har påpekat kommer barnavårdsmyndigheterna att arbeta under ett slags „korstryck“..14)

I de nordiska länderna har det ofta framförts önskemål om att barnavårdsnämnderna måtte förstärkas med specialistmedlemmar. Därvid har man ibland avsett, att nämnderna borde utökas med en jurist, vilket redan har skett i Danmark och Norge. ${ }^{15}$ ) På senare tider har man betonat vikten av att få psykologisk och psykiatrisk sakkunskap i nämnderna och behovet av kontakt med rådgivningsbyråer för uppfostringsfrågor och barnpsykiatriska forskningsanstalter. Barnavårdsnämndernas nyckelställ-

14) Se Christie, Sociologiske meddelelser 1961, s. 83; Persson, dito s. 108.

15) Önskemål i samma riktning bl. a. i de utlåtanden, som fogats till svenska Brottsbalkens förarbeten; se även Ekelöf, NKA 1958, s. 53-54. 
ning när det gäller de yngre åldersklasserna gör denna effektiveringsåtgärd utomordentligt viktig. ${ }^{16}$ )

Åtalseftergiftens kriminalpolitiska ändamålsenlighet kan endast klarläggas genom specialundersökningar. Sättet för barnavårdens anknytning synes i de olika länderna ha ordnats på olika sätt. I Norge blev år 1957 endast $20 \%$ av dem, som erhållit åtalseftergift, föremål för barnskyddsåtgärder, medan motsvarande procenttal i Danmark var $64 \%$ (av dessa placerades $25-30 \%$ i anstalt).${ }^{17}$ )

Uppgifter om återfallsfrekvens står att få från Danmark, Norge och Sverige. I Danmark konstaterades, att bland dem, som år 1953 hade erhållit åtalseftergift (638 personer), ungefär $46 \%$ under observationstiden hade begått nya brott, och att återfallsfrekvensen hade varit störst bland dem, som av barnavården placerats $\mathrm{i}$ anstaltsvård. Dessa representerade tydligen samtidigt den svåraste delen av klientelet. ${ }^{18}$ ) I Norge återföll enligt Christies undersökning av samtliga år 1933 födda personer $19 \%$ av dem, som erhållit åtalseftergift enligt straffprocesslagen och $37 \%$ av dem, som erhållit åtalseftergift i stöd av barnavårdslagen. $\left.{ }^{19}\right)$ Enligt en undersökning, som just nu pågår i Sverige, återföll $35 \%$ av dem, som första gången blivit föremål för åtalseftergift; av hela materialet återföll $40 \%$; bland dem, som blivit föremål för barnavårdsmyndigheternas åtgärder, var motsvarande siffra $66 \% .^{20}$ ) Ytterligare undersökningar, $\mathrm{i}$ vilka man skulle sträva till att undvika de olikheter, som föranledes av klientelets olika sammansättning, vore tydligen nödvändiga.

\section{Påföljdseftergift.}

I Finland har systemet med påföljdseftergift för lagöverträdare under 18 år tillämpats sedan år 1943, då lagen om unga förbrytare trädde i kraft. Påföljdseftergiften kompletterar på ett lämpligt sätt åtalseftergiften t. ex. i sådana fall, då skuldfrågan icke kan utredas utan rättegång eller då målsäganden har väckt åtal. Institutet påminner om den s. k. anglosaxiska villkorliga domen, men det innefattar ingen prövotid och ingen övervakning inom kriminalvården. Det står nära den i Sverige år 1952 genomförda påföljden „skyddsuppfostran“ och Brottsbalkens förslag om „överlämnande till särskild vård“, den i Norge år 1955 genomförda påföljden ,undlate å idømme straff“ (§ 55 mom. 2) samt

16) Se t. ex. Sveri, St.meld. nr 51, s. 89; Norell, NK§ 1959, s. 64; Bexelius, NKA 1958, s. 30 ; Anttila, JFT 1962, s. 48.

17) Andenæs, Norges Børnevern 1959, nr 8-9; Waaben, NKÅ 1959, s. $77-78$.

18) Betænkning 1959 , s. $33-34$.

19) Christie, Unge norske lovovertredere, s. 57.

20) Se Sveri, Preliminära uppgifter rörande de lagöverträdare som år 1956 erhållit åtalseftergift enligt 1944 års lag (stencil.). 
den i Danmark år 1959 föreslagna ,retslig skyldafgørelse“. Enligt finländsk lag avstår domstolen, sedan den först besvarat skuldfrågan jakande, från att döma till straff och underrättar därefter barnavårdsnämnden om sitt beslut.

En undersökning i Finland visar, att 26,5\% av dem, som erhållit påföljdseftergift, hade dömts för ett nytt straffregisterbrott inom fem år från beslutet. Materialet för Helsingfors utvisade, att återfall förekom oftast bland dem, som blivit föremål för barnavårdsåtgärder; dessa hade en återfallsprocent på 32..21)

I detta sammanhang är det kanske skäl att fästa uppmärksamheten vid en terminologisk fråga. I de svenska och danska lagarna användes såsom en ny påföljd ,överlämnande till särskild vård“. Vore det icke skäl att ändra de nuvarande termerna påföljdseftergift och åtalseftergift — då det faktiskt är frågan om att byta ut straffet mot vårdåtgärder — till sådana termer, som icke innehåller någon antydan om en mild påföljd eller om att ingen påföljd alls kommer att tillämpas. „Eftergiften“ kan ju de facto leda till åratals anstaltsbehandling.

\section{Villkorlig dom ${ }^{22}$ )}

Villkorlig dom har redan i många år varit en påföljd, som i synnerhet tillämpats på unga lagöverträdare. Till följd av den utbredda användningen av åtalseftergift kommer villkorlig dom numera framförallt $i$ fråga för personer mellan 18-20 år. Jämsides med den tidigare förhärskande kontinentala formen börjar den anglosaxiska formen, som innebär, att straff icke utsättes, att vinna tillämpning. Fogandet av övervakning och andra villkor till den villkorliga domen har utvecklat denna påföljd från varning till ,kriminalvård i frihet“. De aktuella frågorna under senaste år har varit bl. a., huruvida det är ändamålsenligt att genom villkorlig dom bestämma, att också en specialbehandling villkorligen skall uppskjutas (t. ex. intagning i ungdomsfängelse); huruvida det i systemet bör inrymmas möjlighet att använda villkorlig dom utan övervakning; huruvida det bör utvecklas en sådan form, i vilken det såsom förutsättning för undvikande av straff uppställes långt gående villkor, t. ex. bestämmelse om att vederbörande bör söka sig till vårdanstalt; huruvida man jämte villkorlig dom bör kunna ådöma också bötesstraff för samma brott; huruvida villkorlig dom kan förenas med kortvarig anstaltsbehandling och därpå följande eftervård i frihet. De flesta av dessa frågor har redan grundligt behandlats i de nordiska länderna och några av dem har t. o. m. blivit avgjorda genom lagstiftning.

I praktiken uppstår de flesta problemen i samband med över-

21) Mälkki, NKfK 1961, s. 12 och 15.

${ }^{22}$ ) Termen användes här i vidsträckt betydelse. 
vakningssystemet; är det ändamålsenligt att förverkliga övervakningen på åtgärd av staten eller av enskilda personer eller enskilda organisationer; bör övervakningen vara en huvudsyssla, en avlönad bisyssla eller en helt oavlönad syssla; huru bör övervakarnas utbildning ordnas. I de länder, där man såsom villkor för uppskovet med straffet, uppställer bestämmelser om anstaltsvård, kan det uppstå svårigheter på grund av bristande utrymme i anstalterna. Flera av dessa problem blir aktuella, då man övergår till ett system, där kort anstaltsvistelse kan förenas med eftervård i frihet (det svenska förslaget till Brottsbalk).

I de nordiska länderna har några undersökningar gjorts beträffande den villkorliga domens individualpreventiva verkan. I Danmark har Christensen vid en undersökning i Aarhus polisdistrikt kommit till resultat, att återfall bland villkorligt dömda under en femårig observationstid förekommit i $45 \%$ av fallen, bland de ovillkorligt dömda har återfall förekommit i $56 \%$ av fallen; ungefär samma resultat erhålles, då endast de personer, som dömts för tjuvnadsbrott, beaktas. I allmänhet har återfall varit vanligare bland dem, som ställts under övervakning än bland dem, som icke har övervakats. ${ }^{23}$ ) Wolf kom till resultatet, att om man håller ålder, tidigare levnadslopp och straffets längd konstanta, finner man icke några betydande olikheter mellan villkorligt och ovillkorligt dömda, och icke heller mellan dem, som ställts under övervakning och dem, som lämnats utan övervakning. ${ }^{24}$ ) Christies undersökning visar en återfallsfrekvens på $18 \%$ hos villkorligt dömda och en frekvens på endast $9 \%$ hos ovillkorligt dömda, men det framgår icke $\mathrm{i}$ vilken mån ålder och brottstyp hållits konstanta. ${ }^{25}$ ) I en svensk undersökning erhöll Eriksson-Jansson-Larsson för 15-17 åringar en återfallsprocent på 34 bland dem, som ställts under övervakning och en procent på 86 bland dem, som förordnats till anstalt; motsvarande procenttal för 18-20 åringar var 34 och $47 \%$. Materialet omfattade personer, som första gången blivit föremål för påföljd, och observationstiden var fem år. ${ }^{26}$ ) I Inghe-Lindbergs svenska undersökning var återfallsfrekvensen under fem års observationstid 23.3 $\pm 0.9 \%$ bland villkorligt dömda, $62.3 \pm 3.9 \%$ bland dem, som förordnats till ungdomsfängelse, $24.9 \pm 0.9 \%$ bland dem, som dömts till kortvariga frihetsstraff $\mathrm{i}$ vanliga fängelser samt 50.1 $\pm 1.5 \%$ bland dem, som hade utstått långvariga frihetsstraff. ${ }^{27}$ ) Anttila har indelat dem, som åren 1948-1951 första gången dömdes till frihetsstraff, enligt ålder och sanktion och därvid kommit till resultatet, att återfall varit något allmännare bland

$\left.{ }^{23}\right)$ Christensen, Unge lovovertrædere, s. $86-87$.

24) Wolf, NTfK 1961 , s. 64.

$\left.{ }^{25}\right)$ Christie, Unge norske lovovertredere, s. 57.

${ }_{27}^{26}$ Se Eriksson-Jansson-Larsson, SOU 1956:55, s. 51.

${ }^{27}$ ) Se Inghe-Lindberg; SOU 1956:55, s. 87. 
ovillkorligt dömda (bland villkorligt dömda 15-17 åringar $32 \%$ och bland ovillkorligt dömda $36 \%$; bland villkorligt dömda 18 20 åringar $29 \%$ och bland ovillkorligt dömda $35 \%$ ). Om en uppdelning även sker enligt brottstyp, är återfallsfrekvensen bland såväl för egendomsbrott som för våldsbrott villkorligt dömda 15-17 åringar mindre än bland ovillkorligt dömda i motsvarande ålder (för tjuvnadsbrott är talen 34 respektive $37 \%$, för våldsbrott 22 respektive $47 \% .^{28}$ ) Dessa frågeställningar kan endast belysas genom ytterligare forskning.

\section{Bötesstraff.}

Böter är en påföljd, som i vissa nordiska länder tillämpas synnerligen allmänt på unga lagöverträdare, även om det är svårt att ur statistiken få noggranna uppgifter härom. Bötesstraffet är, trots sin repressiva natur, i många fall uppenbart en nödvändighet och ofta, t. ex. för trafikkbrott, de lämpligaste bland straffen. För förvärvsarbetande innebär böter en förhållandevis lindrig sanktion; annorlunda förhåller det sig med de ungdomar, som icke har förvärvsinkomster och beträffande vilka det sålunda kan bli fråga om ett förvandlingsstraff i fängelse. Eftersom man icke $\mathrm{i}$ något nordiskt land har ansett sig kunna avstå från att utsätta förvandlingsstraff för böter, som ådömts personer under 18 år, vore det synnerligen erforderligt, att man utvidgade möjligheterna till prövning vid verkställandet av förvandlingsstraffet. I Danmark har man år 1957 genom beslut av justitieministeriet genomfört ett system enligt vilket förvandlingsstraffet icke verkställes beträffande personer under 18 år, förrän saken har prövats i justitieministeriet; dessutom bör polismästaren taga kontakt med den unga lagöverträdarens föräldrar och sålunda ge dem tillfälle att besluta, om de önskar betala böterna.

\section{B. Åtgärder $i$ anstalter.}

Av de åtgärder, som hör till anstaltsbehandlingens område, behandlas här först frihetsstraff i allmänt fängelse och därefter påföljder i specialanstalter. Detta motsvarar också uppdelningen i tidsbestämda och tidsobestämda påföljdsformer, men motsatsförhållandet är relativt, eftersom av de allmänna frihetsstraffen endast de kortvariga är helt tidsbestämda, då en fånge som ådömts ett längre frihetsstraff kan bli villkorligt frigiven. Dessutom har lagen uppställt maximi- och minimitider för den behandling, som sker i specialanstalter, och praxis har ofta utvecklat behandlingstider av standardiserad längd. I fångvårdshänse-

28) Anttila, Lakimies 1959, s. 267-277. 
ende kunde uppdelningen också ske beroende på huruvida verkställigheten sker i öppna eller slutna anstalter och huruvida behandlingen $i$ lagen avsetts att vara och $i$ praktiken blivit långeller kortvarig.

\section{Frihetsstraff $i$ allmänt fängelse.}

Redan i decennier har man i alla länder ansett det oändamålsenligt, att frihetsstraff, som ådömts unga lagöverträdare, verkställes i allmänt fängelse - detta gäller framförallt beträffande de yngre åldersklasserna. Även om åtalseftergift och villkorlig dom $\mathrm{i}$ de nordiska länderna har minskat användningen av ovillkorliga frihetsstraff, framträder samma problem också i dagens diskussion. Åsiktsutbytet har i synnerhet varit livligt i de länder, där ungdomsfängelse ej kan tillämpas på personer under 18 år.

Frågan om placeringen av unga lagöverträdare i en särskild avdelning inom ett fängelse, kan knappast avgöras genom ett lösryckt principbeslut. Det behövs för det första kunskaper om hurudana dessa allmänna fängelser skulle vara och för det andra därom, vilka andra alternativ som står till buds. En möjlighet vore naturligtvis att placera alla unga i ungdomsfängelse, en annan att placera dem i barnavårdens anstalter. Det är skäl att noggrant överväga, huruvida olikheten mellan dessa anstalter och en ungdomsavdelning i ett allmänt fängelse skulle bli särskilt stor. Användningen av öppna anstalter och specialbehandling är nämligen också möjliga i anslutning till allmänna fängelser.

En ny form för verkställighet av frihetsstraff, vilken i Finland varit $i$ bruk ända sedan slutet av 1940-talet, representeras av statens arbetskolonier. Dessa är närmast avsedda för fängelsefångar, som första gången utstår frihetsstraff och för fångar som utstår förvandlingsstraff för böter. En ung lagöverträdare, som dömts till fängelsestraff under 6 månader eller till förvandlingsstraff för böter, kan placeras i arbetskoloni, likaså den, som dömts till fängelsestraff från 6 månader till 2 år, såvitt han ej förordnas till ungdomsfängelse. ${ }^{29}$ ) Arbetskolonin är en helt öppen anstalt utan vakter och fångkläder. Där betalas till arbetarna en lön, som närapå motsvarar gängse lönenivå.

\section{Specialpåföljder $i$ ungdomsanstalter.}

Ungdomsanstalter, som förutsätter en långvarig anstaltsvistelse, känner man sedan gammalt till både inom barnavården och fångvården. De faktiska olikheterna hos anstalterna på dessa två områden bestämmes bl. a. av traditionerna $i$ vederbörande land, av åldern och „svårighetsgraden“" hos det klientel, som

${ }^{29}$ ) Unga lagöverträdare sammanförs i Finland i två arbetskolonier, där det den 16.2.1962 fanns sammanlagt 40 manliga arbetare under 
kommer till anstalterna. Om man både inom fångvården och socialvården som officiell strävan för anstaltsbehandlingen uppställer uppfostran och undervisning kan olikheterna i praktiken bli ringa. I några länder är anstaltstiderna lika långa, i andra arbetar fångvården med kortare tider än socialvården. I Finland existerar det i nämnda avseende en klar skillnad, eftersom den faktiska vistelsetiden $\mathrm{i}$ ungdomsfängelse är 6 månader till 1 år, medan den i skolhemmen är 3-4 år.

Förordnande till anstaltsbehandling och kvarhållande där är en så långt gående påföljd, att man med nödvändighet skulle behöva bättre kunskaper om anstaltsbehandlingens fördelar och nackdelar än vad som nu står till buds. Den i tiden officiellt omfattade åsikten, att anstaltstidens längd skulle stå i positiv korrelation till anpassningen efter frigivningen, har icke fått något stöd av forskningen. Anstaltsvistelsens verkliga innebörd och verkningar har speciellt undersökts i flera amerikanska sociologiska undersökningar (Clemmer, Sykes, Ohlin, Wheeler) samt i norden i Galtungs undersökning av ett norskt fängelse. ${ }^{30}$ )

Bland de menliga följder som ansluter sig till långvarig anstaltsvistelse kan nämnas, utom den förstärkning av de antisociala attityderna, som uppkommer genom tillägnandet fängelsesamfundets normer, framförallt tillvänjning till anstaltsmiljön och ett psykiskt fjärmande från tillvaron $i$ det fria. ${ }^{31}$ ) Dessa frånsidor jämte de svårigheter, som fången vanligen har att efter frigivningen få arbete och bli godkänd i annan än kriminell miljö, bör således vid övervägandena ställas i motsats till den yrkesundervisning och annan specialbehandling, som blir möjlig vid långvarig anstaltsvistelse. Det skulle behövas mera undersökningar både beträffande den „optimala“ tiden och beträffande verkningarna av tidsbestämd och tidsobestämd behandling.

En effektivering av ungdomsanstalterna har under årtionden varit en omhuldad tradition inom fångvården. Strävan har gått ut på att åstadkomma ett verkligt positivt uppfostringsprogram, genom vilket anstalten skulle bli ,mera lik en skola än ett fängelse", såsom det framhålles i rapporten från det möte som hölls av FN:s konsultativa grupp i Geneve år 1960. Som ett tecken på att det icke är omöjligt att få den unga lagöverträdaren att själv godkänna fängelsetiden som utbildningstid må nämnas, att det ibland har hänt att en fånge, som redan skulle ha haft möjlighet att bliva villkorligt frigiven, frivilligt har stannat kvar för att

30) Clemmer, Donald: The Prison Community, 1 uppl. 1940; Ohlin, Lloyd E.: Sociology and the Field of Corrections, 1958; Sykes, Gresham $M$ : The Society of Captives, 1958; Wheeler, Stanton: Socialization in Correctional Communities, American Sociological Review 1961, Vol. 26, Number 5; Galtung, Johan: Fengselsamfunnet, 1959.

31) Se Blomberg, Nordiskt Kriminologiseminarium 1959, s. 125. 
avsluta sin kurs vid den yrkesskola, som är ansluten till Centralfängelset i Riihimäki.

En särskild typ av anstalter är vårdanstalterna för svårhanterliga fall, som behöver särskild behandling. Inom fångvården torde Roxtuna vara det mest typiska exemplet i de nordiska länderna. Det skulle tydligen behövas flera sådana anstalter, vilket bl. a. har konstaterats vid kriminalistföreningarnas möten. ${ }^{32}$ )

I norden känner vi genom redogörelser och litteratur de ungdomsanstalter för kortvarigt frihetsberövande, som användes i olika europeiska länder (t. ex. de olika formerna av „Jugendarrest" i Tyskland, „,detention centres“ och ,,attendance centres“ i England.$^{33}$ )) Dylika anstalter har ofta - med skäl eller utan ansetts vara radikala motsatser till den traditionella behandlingsanstalten. ${ }^{34}$ ) Kortvarigheten $\mathrm{i}$ frihetsberövandet behöver visserligen icke $\mathrm{i}$ och för sig förutsätta att anstalterna blir enbart „straffande“ eller „förvarande“, även om den korta tiden begränsar ett grundligare behandlingsprogram. Då man överväger ett eventuellt införande av sådana nya anstaltsformer i det nordiska systemet, bör man fästa uppmärksamhet bl. a. vid huruvida man huvudsakligen skulle komma att giva denna kortvariga anstatsbehandling i stället för den nuvarande långvariga anstaltsbehandlingen eller i stället för den nuvarande kriminalvården i frihet. Knappast skulle man ens i anstalter för kortvarigt frihetsberövande kunna undvika, att det skulle uppstå nya smågrupper bland fångarna med förstärkt identifikation med förbrytarrollen. Först på experimentell väg skulle man synbarligen erhålla resultat, vilka kunde jämföras med de erfarenheter som erhållits i övriga europeiska länder. ${ }^{35}$ )

\section{Specialfrågor.}

Rannsakningsfängelse. Användningen av rannsakningsfängelse för unga lagöverträdare har konstaterats vara ett allvarligt problem. ${ }^{36}$ ) Missförhållandet är synnerligen svårt att rätta till, ty förvaring i allmänna anstalter har lika litet som användning av specialanstalter visat sig vara lyckad. I allmänna fängelser kommer den unga lagöverträdaren i kontakt med vuxna lagöverträ-

32) Se NKÅ 1958 och 1959; Sveri, St meld. nr 51, s. 94 .

33) Se prof. Sieverts referat och därpå följande diskussion, NKÅ 1959 ; Förslaget till Brottsbalk, s. 86.

34) Christensen, Unga lagovertrædere, s. 75, skildrar sina erfarenheter av den engelska inrättningen såhär: „Adskilligt tyder iøvrigt på, at shockbehandlingens indf $\varnothing$ relse i det engelske reaktionssystem overfor unge lovovertrædere i højere grad er udtryk for en indrømmelse til repressive synspunkter end for særlige forventninger til dets stabiliserende indflydelse".

$\left.{ }^{35}\right)$ Se t. ex. Mc Clintock, Attendance Centres, London 1961.

36) Se United Nations Report 1960. 
dare, i små specialanstalter åter har det psykiska trycket på internerna enligt gjorda erfarenheter blivit alltför stort och ordnandet av sysselsättning har varit svårt. Inrättandet av specialanstalter torde likväl även $i$ fortsättningen böra planeras. ${ }^{37}$ ) Men på samma gång borde man även tänka på reformer i den riktningen, att man överhuvudtaget försöker undvika rannsakningsfängelse, vilket man enligt bestämmelserna i vissa länders lagstiftning redan bör göra beträffande unga, och att man försöker göra vistelsetiden i rannsakningsfängelse kortare genom rationaliseringsåtgärder.

Skadestånd. Den nutida ungdomskriminaliteten av allvarligare art domineras av egendomsbrotten och frågan om skadestånd kommer regelbundet upp till debatt. Ofta har det framförts sådana tankegångar, att det vore bra för den unga lagöverträdaren, om han genom arbete $\mathbf{i}$ anstalt skulle komma att ersätta den skada, som han förorsakat. Detta skulle likväl av allt att döma i praktiken leda till oskäligheter och skulle i betänkelig grad närma sig forna tiders bysättning. Å andra sidan borde samhället se till att det icke genom sitt eget reaktionssystem försvårar möjligheterna att ersätta skadan. Ett fängelse där normal arbetslön utbetalas till fångarna vore ur denna synpunkt att rekommendera, eftersom en del av inkomsterna då kunde innehållas för erläggande av skadestånd.

Sociala sanktioner, som ansluter sig till påföljdssystemet. Till påföljdssystemet ansluter sig flera, dels på legala grunder, dels i praxis uppkomna tilläggspåföljder, vilka lätt kan mångdubbla strängheten hos de tillämpade påföljderna eller förhindra lagöverträdarens återanpassning i samhället. Skolan kan sålunda relegera en elev, som i form av åtalseftergift eller villkorlig dom har givits möjlighet att ännu försöka sitt bästa i det fria samhället; en frigiven fånge förlorar kanske möjligheten att återvända till sitt gamla arbete då han ej kan återfå sitt indragna körkort; en person, som domstolen önskat giva en kännbar lärdom i form av ett kortvarigt frihetsstraff, förlorar sin anställning, o. s. v.

Påföljdernas inkonsekvens beror delvis på olika myndigheters skiftande inställning till kriminalpolitiska problem, men oftast helt enkelt på att det icke förekommer tillräcklig koordination av påföljdssystemet. Genom sociologiska undersökningar kunde man kartlägga dessa inkonsekvenser och påvisa de missförhållanden, som genom dem uppstått i den sociala kontrollen. Det kan här nämnas, att skolstyrelsen i Finland år 1958 riktade en uppmaning till läroverkens rektorer, att icke relegera villkorligt dömda unga lagöverträdare enbart på grund av den villkorliga

37) Se danska Betænkning 1959, s. 12-17, samt diskussionen i NKA 1959 . 
domen samt påpekade, att bötesstraff, åtalseftergift och påföljdseftergift icke får utgöra motiv för relegering.

Ovan har behovet av kriminologisk forskning för utvecklingen av kriminalpolitiken poängterats. Det finns också en del sådana kriminalpolitiska och andra praktiska åtgärder, genom vilka man kännbart skulle kunna öka den vetenskapliga forskningens möjligheter. Främst borde de statistiska uppgifterna $i$ formellt hänseende göras mera jämförbara, så att man antingen ur en samnordisk publikation eller ur de statistiska framställningarna från de olika nordiska länderna, utan specialundersökningar kunde fördelaktimförbara uppgifter. Ur forskningens synpunkt vore det så många olika på i påföljdssystemet skulle skapa och utpröva igenom skulle få möjdsformer som möjligt, eftersom man härolika påföljdernas ajlighet att snabbare skapa sig en bild av de såsom t. ex. den planerade lålsenlighet. För nya påföljdsformer de legala gränserna $i$ de olika länderna anstaltsbehandlingen, borde likartat sätt, så att man vid undersökna bestämmas på möjligast ga faktorer som möjligt konstanta. De påbörjade strävandena att förenhetliga strafflagarna bör därför hälsas med glädje också med tanke på den kriminologiska forskningens framtid.

Inkeri Anttila.

\section{LITTERATUR}

Andenæs, Johs.: Garantier for rettssikkerheten ved administrative avgörelser. Överläggningsämne vid det nittonde nordiska jurist-
mötet. Stockholm 1951 .

- Tenåringskriminaliteten - en utfordning til barnevernet. Norges Barnevern nr. 8-9, s. $1-14$. Oslo 1959.

- Om muligheden af gennem empirisk forskning at belyse straffesystemets generalpræventive virkninger. Det tredie nordiske kriminologiseminar. Krogerup 1960 (stencil).

Anttila, Inkeri: Nuori lainrikkoja. Porvoo-Helsinki 1952. Ehdollisen rangaistustuomion erityisestävän vaikutuksen ar-
viointia. Lakimies 1959 , s. $272-278$.

Om rättsskyddet och likställigheten i det påföljdssystem, som given av Juridiga gärningar begångna av barn. Tidskrift, ut-

Aulie, Andr.: Om behandlingen 1948 , s. $28-43$. Stockholm 1949 lovovertredere. NKA $1947-$ Aktuelle krimin Stockholm 1949.

til dem. Nordisk Kriminalteknisk påtalemyndighetens stilling 49-63.

Berg, Axel, Reaktioner overfor unge lovovertrædere. NTfK 1957, s.

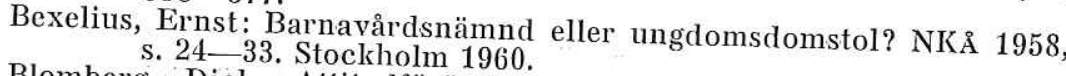

Blomberg, Dick: Attitydförändringar hos ungdomsfängelseklientel. Nordiskt kriminologiseminarium. Sigtuna 1959 (stencil.)

Bovet, L.: Psychiatric Aspects of Juvenile Deling 1951 . 
Bruun, Kettil-Hartman, Tor: Nuorisorikollisuutemme. Lakimies 1961, 6. vihko. s. $627-635$.

Gloward, Richard A. - Ohlin, Lloyd E. : Delinquency and Opportunity. Illinois 1960 .

McClintock, F. H.: Attendance Centres. Cambridge Studies in Criminology. London 1961.

Christiansen, Karl O.: Den forventede kriminalitet i de store fødselsårgange. NTfK 1958 , s. 4-18.

Ungdomskriminaliteten i Danmark 1933-55. Straffelovskommissionens betænkning vedrørende ungdomskriminaliteten Nr. 232, 1959, Bilag 1.

- Den danske ungdomskriminalitets udvikling i de seneste år. NTfK 1961, s. $274-275$.

- Industrialization and urbanization in relation to crime and juvenile delinquency. International Review of Criminal Policy No 16. October 1960 , s. $3-8$.

Christiansen, Karl O. - Norskov Nielsen, L. : Tiltalefrafald mod børneforsorg. NTfK 1958, s. $220-237$.

Christensen, Erik: Unge lovovertrædere. København 1957.

Christie, Nils: Unge norske lovovertredere. Oslo 1960.

- Reaksjonenes virkninger. NTfK 1961, 2-3 hefte, s. $129-144$

- Barnevernsnemndenes Sosiologi. Sociologiske Meddelelser 6. serie 2 hæfte 1961, s. 83-98. Udgiver: Sociologisk Institut, Københavns Universitet.

Dahlberg, Gunnar - Lindberg, Torgny: Om frekvensen av återfall i brott. SOU 1944:50, s. 339-386. Stockholm 1944.

Eloranta, Viljo: Nuorisorikollisuudesta ja sen nykyisen kasvun erityissyistä. Lakimies 1961,1 vihko, s. $151-188$.

Empey, LaMar T. and Rabow, Jerome: Experiment in Delinquency Rehabilitation. American Sociological Review, October 1961, Volume 26, Number 5, s. 679-695.

Eriksson, Torsten: Amerikanska experimentanstalter. SOU 1950:47, Bilagor, s. 136-154. Stockholm 1950.

Eriksson, Torsten - Janson, Carl-Gunnar - Larsson, Ulla: Återfall i brott bland unga lagöverträdare. SOU 1956:55, Bilagor, s. $35-82$. Stockholm 1956.

Fyvel, T. R.: The insecure offenders. London 1961.

Helasvuo, Kaarlo: Om slkyddsuppfostran av barn och ungdom. NKA 1948-1949, s. 151-160. Stockholm 1950.

Hermansson, Bertil - Björkenhed, Sten — Björkberg, Roland: Ungdom och brott. Lund 1959.

Heumann, Maths. : Åtalseftergift, påföljdseftergift, nåd. NKÅ 1951-1952, s. 2-21. Stockholm 1953.

Holmberg, Carl: Korttidsbehandling av unga lagöverträdare. NK§ 1959, s. 52-60. Stockholm 1961 .

Hult, Bengt: Förslaget till skyddslag. Påföljdssystemet för unga lagöverträdare. NKÅ 1957, s. 23-35. Stockholm 1959.

Inghe, Gumnar - Lindberg, Torgny: Recidivrisken vid olika brottstyper med särskild hänsyn till inflytandet av alkoholmissbruk. SOU 1956:55, Bilagor, s. 83-99. Stockholm 1956.

Lampi, Kauko: Nuorisorikollisuuden määrällinen ja laadullinen tarkastelu kymmenvuotiskauden 1951-1960 tilastoista. Rikollisuutta vastaan 1961 , s. $25-36$.

Lunden, Walter A.: War and Delinquency. Prepared for Social Defence Section of the Bureau of Social Affairs Department of Economics and Social Affairs. United Nations 1960.

Middendorff, Wolf : New Forms of Juvenile Delinquency: Their Origin, Prevention and Treatment. United Nations 1960. 
Mälkki, Heikki: Några iakttagelser beträffande påföljdseftergift för unga förbrytare i Finland. NTfK 1961, 1. hefte, s. 1-16.

Möglestue, I. C.: Kriminalitetsutviklingen i Norge etter krigen - særlig med tanke på ungdomskriminaliteten. NKÅ 1958, s. 62-73. Stockholm 1960.

- Den aktuelle kriminalitetsutvikling i Norge. Vernelagsnytt 1960 , s. $4-14$.

Nyqvist, Ola: Juvenile Justice. Uppsala 1960.

Persson, Britt-Mari: Barnavårdsnämnd och åklagaremyndighet vid beslut om åtalseftergift. Sociologiske Meddelelser 6. serie 2 hæfte 1961, s. 99-112. Udgiver: Sociologisk Institut, Københavns Universitet.

Rengby, Sven: Brottslighetsutvecklingen i Sverige under 1950-talet. NTfK 1961, s. 276-300.

Salmiala, Bruno A.: Sosiaalilautakunnat taistelussa nuorisorikollisuutta vastaan. Defensor Legis 1959, N: o 5-6, s. $171-184$.

Strahl, Ivar m. fl.: Om påföljder för brott. Stockholm 1955.

Sveri, Knut: Preliminära uppgifter rörande de lagöverträdare som år

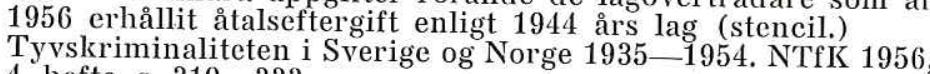
4. hefte, s. $319-333$.

Ungdomskriminalitet i Sverige og Norge. Svensk Juristtidning 1957 , s. $151-161$.

- Barnekriminaliteten. NTfK 1959, 2. hefte, s. 132-147.

- Kriminalitet og alder. Uppsala 1960.

Om barne- og ungdomskriminaliteten i Norge. St.meld. nr. 51 (1960-61), Socialdepartementet, Vedlegg 2, s. 29-96. Oslo 1961.

Sveri, Knut - Nyqvist, Ola: Eksempler på analyser av kriminalpolitiske tiltak. Nordisk forskningsseminar i kriminologi, Lillehammar 1958 (stencil).

Tappan, Paul W.: The Competent Authorities. General Report. Fifth International Congress for Social Defence. Stockholm 1958.

Tauleri, Heikki: Lagstiftningen angående unga lagöverträdare. NKÅ $1949-1950$, s. $192-198$. Stockholm 1950.

Thomas, Rose C.: Recent efforts to handle juvenile delinquency. Sociology of Crime, edited by Joseph S. Roucek, s. 271-298. New York 1961.

Trankell, Arne - Börjeson, Bengt: Ungdomsbrottslingars prognos efter olika slag av behandling. Forskningsrapport från pedagogiska Institutionen, Stockholms Universitet. Nr. 1 Januari 1961, Nr. 2 Maj 1961.

Waaben, Knud: Reaksjonssystemet overfor lovovertredere mellom 14 og 18 år. NKÅ 1959, s. 74-88. Stockholm 1961.

$\overrightarrow{-}$ Inledning til dansk kriminalpolitik. København 1961 (stencil.)

Verkko, Veli: Finlands återgång till fredstida brottslighet. NK尺̊ 19511952, s. 183-197. Stockholm 1953.

Wolf, Preben: Om recidiv efter betinget dom. NTfK 1960, 4. hefte, s. $314-329$ och 1961,1 . hefte, s. $49-72$.

Kommittebetänkanden och rapporter:

Danmark: Betænkning vedrørende forsorgen for børn og unge, som har særlige tilpasningsvanskeligheder. $\mathrm{Nr} .77,1953$.

Straffelovskommissionens betænkning vedrørende ungdomskriminaliteten. Nr. 232, 1959.

Betænkning vedrørende ungdomskommissionens betænkning om den tilpasningsvanskelige ungdom. Nr. 252, 1960. Betænkning fra børne- og ungdomsforsorgens pædagogiske nævn. Nr. 255, 1960. 
Norge: Om barn og ungdom med adferdsvansker. St.meld. nr. 51 (1960-61). Socialdepartementet.

Innstilling fra komitée til å utrede spørsmålet om reformer i fengselvesenet 1956 .

Sverige: Skyddslag. Strafflagberedningens slutbetänkande. SOU 1956:55.

Ungdomsbrottslighet. SOU 1959:37.

Rättssäkerheten vid administrativa frihetsberövanden. SOU 1960:19.

Polisens brottsbekämpande verksamhet. SOU 1961:15.

Kriminalvård i frihet. SOU 1961:16.

Kungl. Maj:ts Proposition 1962:10 med Förslag till Brottsbalk, Del A, B, C.

United Nations: International Labour Organisation. Juvenile Delinquency viewed as a Labour Problem. Geneva 1955. The Prevention of Juvenile Delinquency in selected European Countries. Geneva 1955.

The Prevention of Juvenile Delinquency. Report prepared by the Secretariat. Geneva 1955.

New Forms of Juvenile Delinquency. Their Origin, Prevention and Treatment. Report prepared by the Secretariat. London 1960.

Bericht über die Verhandlungen des 10. Jugendgerichtstages 1956. Köln-Berlin 1959. 